\title{
Die belangrikheid van Kerkgeskiedenis en Kerkreg in die teologiese opleiding en vorming van studente ${ }^{1}$
}

\author{
S J Botha \\ Emeritus-professor: Departement Kerkgeskiedenis \\ Universiteit van Pretoria
}

\begin{abstract}
The importance of Church History and Church Polity in the training and forming of theological students

The Nederduitsch Hervormde Kerk always has always been adamant that its ministers should be trained and formed in a theological faculty at a recognized university, where all the disciplines of theology are lectured. At a recent Church synod, the importance of Church History was questioned. In this paper the argument that Church History is not just important in the curriculum of theology, but indeed indispensable, is put forward. As Church Polity forms part of the Department of Church History at the Faculty of Theology (University of Pretoria), it is also included in the argument.
\end{abstract}

\section{INLEIDING}

Tydens die jongste Algemene Kerkvergadering van die Nederduitsch Hervormde Kerk het ' $\mathrm{n}$ ouderling op vragende wyse die mening uitgespreek dat Kerkgeskiedenis in die opleiding van teologiese studente afgeskaal behoort te word ten gunste van meerdere praktiese toerusting. Sover bekend is dit die eerste keer dat so 'n afwysende mening oor die vak op enige Algemene Kerkvergadering uitgespreek is. Hoewel die Algemene Kerkvergadering nie op enige wyse hierdie mening ondersteun het nie, maar steeds, ten

\footnotetext{
${ }^{1}$ Lesing gehou by die opening van die Hervormde Teologiese Kollege aan die Universiteit van Pretoria op Dinsdag, 5 Februarie 2002.
} 
spyte van die huidige problematiese omstandighede, positiewe besluite geneem het oor die voortbestaan van die vak as deel van die teologiese kurrikulum, was hierdie opmerking waarskynlik wel die rede vir die Hoof van die Hervormde Teologiese Kollege se versoek/opdrag om vanjaar by die aanvang van die akademiese aktiwiteite van die Kollege oor die saak te handel. Dit bring die vraag na vore of hierdie geleentheid gebruik moet word om aggressief apologeties-verdedigend die saak vir die voortbestaan van die vak as deel van die kurrikulum binne die opleiding op te neem. Die feit egter dat die onderwerp nie deur die Hoof van die Kollege in die vorm van 'n vraag geformuleer is nie maar in ' $n$ stelling, laat blyk dat die posisie van Kerkgeskiedenis nie in gedrang is nie, en dat die geleentheid daarom gebruik kan word om positief verantwoording te doen oor die rol en betekenis van die vak in die teologiese opleiding en vorming van studente.

Aanvanklik het die Hoof van die Kollege die vak Kerkreg nie genoem nie. Hy het egter wel die opening gelaat om die formulering te verander. Omdat Kerkreg tradisioneel van die begin af aan Kerkgeskiedenis verbind is en die departement wat dit aangebied het as die Departement Kerkgeskiedenis en Kerkreg bekend gestaan het, het die Hoof nie beswaar gehad dat Kerkreg ook betrek word nie. Verder moet ook in gedagte gehou word dat hoewel Dogmageskiedenis nie afsonderlik genoem word nie, dit ook as onderdeel van Kerkgeskiedenis in hierdie departement aangebied word.

\section{TEOLOGIESE OPLEIDING EN VORMING}

Die studente om wie dit hier gaan, is baie duidelik persone wat die oog het op die predikantskap in die Nederduitsch Hervormde Kerk van Afrika. Onder teologiese opleiding en vorming word twee onderskeie sake bedoel, wat egter onlosmaaklik aan mekaar verbind is en wat een gesamentlike resultaat moet oplewer. Die resultaat moet naamlik 'n kandidaat wees wat voldoen aan die vereistes wat die Nederduitsch Hervormde Kerk vir sy predikante stel.

Vanaf die oomblik dat die Nederduitsch Hervormde Kerk begin dink en praat het van 'n eie opleiding vir sy predikante, was die vereiste van 'n universitêre opleiding, 'n absolute prioriteit (Oberholzer 1967:16, vgl Botha 1981:81). In 1917 het hierdie ideaal vir die Nederduitsch Hervormde Kerk in vervulling gegaan met die vestiging van 'n teologiese fakulteit aan die destydse Transvaalse Universiteitskollege wat later die 
Universiteit van Pretoria sou word. Die Nederduitsch Hervormde Kerk het die Fakulteit Teologies gedeel met die Presbiteriaanse Kerk en elkeen het aanvanklik een dosent aangestel naamlik prof $\mathbf{J}$ H J A Greyvenstein van die Nederduitsch Hervormde Kerk (voltyds) en dr E MacMillan van die Presbiteriaanse Kerk (deeltyds; Pont 1992:259, Oberholzer 1967:20). Prof Greyvenstein is nie alleen verantwoordelik gemaak vir NuweTestamentiese Wetenskap nie, maar ook vir Kerk- en Dogmengeskiedenis en Kerkreg en daarnaas ook nog Dogmatiek (Pont 1992: 259).

Die Nederduitsch Hervormde Kerk het dus 'n opleiding vir sy toekomstige predikante op die oog gehad wat berus het op die hoogste moontlike akademiese en wetenskaplike standaarde. Die vakke wat aangebied is en die dosente wat dit aanbied, moes aan die vereistes en norme van universitêre wetenskaplikheid voldoen. Ook die drie ter sake vakke het dus van die begin af 'n vaste onderdeel van die kurrikulum gevorm. Prof Pont bevind: "Dit is interessant om daarop te let dat Kerkgeskiedenis van die begin af as 'n noodsaaklike deel van die BD- en kerklike eksamen beskou is en dat dit dieselfde gewig as die Bybelwetenskappe in die BD-kursus gehad het" (Pont 1992:261).

Ook ten opsigte van die kandidate wat as voltydse dosente vir die onderskeie vakgebiede oorweeg en aangestel is, is die vereiste gestel dat hulle ten volle gedoktoreer moes wees. Dit was veral ds Jac van Belkum wat reeds op die vergadering van die Kuratorium van 25 Januarie 1917 onverbiddelik die eis gestel het: "Die doctorale eksamen gedaan heeft is nog niet gepromoveerd en valt buiten de wet" (Oberholzer 1967:20).

Op die wyse het die Nederduitsch Hervormde Kerk, wat homself nog altyd gesien en waardeer het as histories en regmatig voortsetting van die Calvinistiese kerk wat via Nederland na Suid-Afrika oorgeplant is, die tradisie waarin hy gewortel is, voortgesit naamlik om die deeglike opleiding van dienaars van die Woord van die begin af 'n saak van groot gewig te maak. Hieroor merk prof Pont op:

Die Kerkhervorming van die sestiende eeu, in beide sy aanvanklik Duitse en Franse vorm, is gedra deur geleerde en gelowige manne bedrewe in hulle kennis van die grondtale van die Skrif, die leer en die geskiedenis van die 


\section{Die belangrikheid van Kerkgeskiedenis}

kerk. Vandaar, dat van die begin af, 'n universitêre teologiese opleiding as 'n noodsaaklik komponent van die lewe en werk van die kerk beskou is.

(Pont 1992:253)

Wat die Hervormde Kerk wou bereik was om sy aanstaande predikante deeglik te laat kennis maak en deeglike begrip te laat ontwikkel vir die Bybels-Reformatoriese teologie wat die kerk as 'n kosbare en ononderhandelbare erfenis waardeer het. Om dit te bereik het die Hervormde Kerk 'n universitêr-wetenskaplike teologiese opleiding as 'n primêre noodsaaklikheid beskou. Daarnaas het die Nederduitsch Hervormde Kerk ook die verwagting gekoester en die vereiste gestel dat teologiese opleiding hand aan hand met die teologiese vorming sou gaan. Aanvanklik is die begrip vorming nie in die Kerkwet saam met die begrip opleiding gebruik nie, maar tog veronderstel. Onder opleiding is die meer formeel akademiese handeling verstaan, terwyl vorming te make gehad het met die informele aankweek van 'n gesindheid en lewenswandel wat hy graag by sy predikante wou sien. Dit was dus nie maar net 'n rasionele akademies-wetenskaplike saak nie, maar wel deeglik ook 'n saak waar die kandidate se gesindheid en lewenswandel wat hulle geskik sou makk vir die predikantsamp in die Nederduitsch Hervormde Kerk met sy eie etos, voor oë gehou moes word.

Aanvanklik is dit nie in die Kerkwet bepaal wie vir die vorming van die studente verantwoordelik was nie, tog was die verwagting in die Hervormde Kerk wel dat die dosente wat deur die kerk aangewys is dit sou doen. Die vereiste ten opsigte van die vorming was ook van die begin af vir die Nederduitsch Hervormde Kerk van baie groot gewig, maar aanpassings moes noodwendig gemaak word veral ten opsigte van wie almal vir die vorming van die studente verantwoordelik was. Die probleem was naamlik dat die Hervormde Kerk die sogenaamde duplex ordo wat vir die teologie in die meeste Europese Universiteite en veral ook aan die Nederlandse Ryksuniversiteite gegeld het, noodwendig moes aanvaar om deel te kon kry aan die Teologiese Fakulteit. Dit het uiteraard meegebring dat die studente nie net aan die voete van Hervormde leermeesters gesit het nie. Die vorming sou dus nie net in 'n "Nederduitsch Hervormde gees" plaasvind nie. Hierbenewens is die argument binne die Nederduitsch Hervormde Kerk self ook na vore gehaal dat so-iets soos 'n neutrale teologiese opleiding nie kon bestaan nie, want óf 
teologie is kerklike teologie óf dit is een of ander vorm van godsdienswetenskap (Pont 1992:258). Die kerklike vorming sou dus buite-kurrikulêr moes geskied. Hierby het ook die argument gekom dat die Transvaalse Universiteitskollege op daardie stadium nog deur en deur 'n Engelstalige inrigting was wat 'n ander kultuur- en lewensopvatting geadem het wat ook nog grootliks vyandig was teenoor die Afrikaner. Prof Greyvenstein se argumente teen hierdie besware het daarop neergekom dat:

- 'n blote struktuur nie die absolute waarborg was van 'n kerklik-bepaalde of selfs konfessionele opleiding nie;

- die kerk self, deur middel van sy vergaderings moes toesien dat die inhoud en kwaliteit van die opleiding voldoen het aan die vereistes wat die kerk ten opsigte van die leer en lewe van sy voornemende predikante stel (Pont 1992:258); en

- 'n oortuigde kerkman-teoloog, selfs in 'n neutrale struktuur, nog die regte opleiding en vorming kan aanbied.

Greyvenstein het hierdie argumente van hom inderdaad self prakties uitgeleef. Met opregte oortuiging kon hy aan sy kritici sê: "Het lijkt mij of die twee broeders denken dat alleen Ds MacMillan en niet ik, invloed heeft op onze studenten. Ze vergeten, dat ik met hun omga als een vader met zijn kinders. Er is geen gevaar voor mislukking" (Pont 1992:259).

Greyvenstein het ongetwyfeld van die begin af 'n positiewe invloed uitgeoefen ten opsigte van die teologiese vorming van die studente wat Oberholzer in 1967 van hom laat sê het: "Met wetenskaplike onderleg was in prof Greyvenstein 'n diepe geloofserns en 'n waardige persoon verbind. Hy geniet tot vandag toe die hoë agting van almal wat hom ken. Vir die studente was en bly hy 'Vadertjie', 'n erenaam wat geen uitleg behoef nie" (Oberholzer 1967:20).

Die vormingsaspek van die studente het vir hom ook nog 'n ander gestalte gehad en juis daarom is met behulp van prof $\mathrm{S}$ P Engelbrecht in sy huis die Hervormde Teologiese Vereniging Van der Hoff in 1924 tot stand gebring om die band tussen studente en dosente te verstewig en juis ook die vormingsverantwoordelikheid van die dosente te vergemaklik (Louw 2000). Trouens volgens Pont was dit juis Greyvenstein en 
Engelbrecht wat "die studie aan die Fakulteit algaande gestuur het in die rigting van 'n kerklike, dit wil sê konfessioneel-bepaalde Fakulteit wat teologie in die kerk en ten behoewe van die kerk beoefen volgens die aanvaarde riglyne wat die kerk gestel het" (Pont 1992: 259). Hierdie proses is verder vergemaklik toe daar na 1935 met die tot stand kom van 'n Fakulteit met twee parallelle fakulteitsafdelings sonder meer afgestap is van die duplex ordo (Pont 1992:261). Mettertyd het die Hervormde Kerk sy beskouing en wense ten opsigte van beide die opleiding en vorming van die toekomstige predikante, wat altyd ten nouste aan mekaar gekoppel is, ook uitdruklik in sy kerkordelike reëlings opgeneem. Vanaf 1917 is die plek waar die opleiding moes plaasvind baie duidelik uitgespel naamlik die Universiteit van Pretoria (Kerkwet 1925:45). Aanvanklik is daar nie oor die vorming van die kandidate enige bepalings gemaak nie, soos watter profiel die kandidaat by voltooiing van die opleiding en vorming moes vertoon of wie vir die vorming verantwoordelik was nie. Daar is wel bepaal dat, voor 'n kandidaat tot die proponentseksamen toegelaat word, hy 'n bewys van goeie gedrag, afgegee deur die professore, moes inlewer (Kerkwet 1925:48). Ook uit hierdie bepaling van die Kerkwet (1925) is dit duidelik dat die Hervormde Kerk vanaf die begin "onoffisieel" van sy professore verwag het om nie net die opleiding nie, maar ook die vorming van die studente ter hand te neem. Uit die genoemde argumente van Greyvenstein en sy en Engelbrecht se optrede, is dit ook af te lei dat dit ook so van die begin af deur die professore verstaan en aanvaar is.

In die tans geldende Kerkorde Ordinansie 2.1.1.1 (d) geld dit as 'n vereiste dat die Proponentseksamenkommissie onder andere moet vasstel of 'n kandidaat se gesindheid en lewenswandel gedurende die opleiding so gevorm is dat die kandidaat inderdaad vir die predikantsamp geskik kan wees. Die opdrag aan die dosente word ook baie duidelik omskryf naamlik:

\section{Ordereël 2.1.6.1}

\section{Predikante wat teologie doseer}

(a) behartig teologiese opleiding en vorming van voornemende predikante van die Kerk en ander studente

(b) hou opsig oor die leer, gedrag en vordering van studente 
(c) bevorder die Bybels-Reformatoriese teologie deur navorsing, publikasie, voordragte en dosering, en gee leiding by nagraadse studie ... .

Selfs onder die huidige veranderde en vir die Hervormde Kerk moeilike omstandighede, waarin die eie selfstandige teologiese fakulteitsafdeling prysgegee moes word en die kerk gedwing is om 'n nuwe struktuur te aanvaar, volhard die kerk met die vereiste dat sy predikante aan 'n universiteit en dan steeds aan die Universiteit van Pretoria opgelei en gevorm sal word. Daarom bepaal die Kerkorde in Ordinansie 2.1.1 uitdruklik:

\section{Opleiding en vorming van Dienaars van die Woord}

Voornemende predikante van die Kerk word, kragtens die ooreenkoms met die Universiteit van Pretoria, opgelei in die Fakulteit Teologie aan daardie Universiteit met die samewerking van die Hervormde Teologiese Kollege (HTK).

Die lang kontraktuele verbintenis van die Hervormde Kerk met die Universiteit van Pretoria, het daartoe meegewerk dat die kerk nie meer soos vroeër in sy Kerkorde uitdruklik bepaal watter vakke in die opleiding gevolg moet word nie. Besluite deur die Algemene Kerkvergadering word as voldoende geag. Ook nie oor wat die vorming presies behels word enige voorskrifte in die Kerkorde gevind nie. Dit wil voorkom of die Hervormde Kerk die vakmanne, by wie se aanstelling hy 'n beslissende sê gehad het, en wat self reeds gevormde predikante was, tot dusver volkome daarmee vertrou het. Hierdie vanselfsprekendheid sal, in die lig van toekomstige verwikkelinge waaroor nou nog slegs gespekuleer kan word, voortdurend deur die kerk noukeurig heroorweeg moet word.

Opsommend kan gestel word dat die Hervormde Kerk se vereiste steeds, dit wil sê vandag in hierdie tyd, is dat sy aanstaande predikante universitêr opgelei en daarmee saam behoorlik gevorm moet word om geskik vir die predikantsamp in die kerk te kan wees. Wat nou aan die orde gestel moet word is die vraag of die vakke Kerkgeskiedenis en Kerkreg steeds belangrik genoeg is om tot voldoening aan hierdie vereiste, 'n bydrae te kan makk. 


\section{KERKGESKIEDENIS}

Kerkgeskiedenis as 'n selfstandige dissipline of vakwetenskap binne die geheel van die teologiese wetenskap, is relatief jonk (Stoop 1973:86), hoewel nie die jongste van die teologiese dissiplines nie (vgl Johansen 1973:171). Kerkhistoriografie is egter 'n baie ou bedryf en hoewel Eusebius van Caeserea (260-339) gewoonlik as die vader van die kerkgeskiedskrywing aangedui word, kom Lukas, met die Handelinge van die Apostels met goeie reg ook in aanmerking (Stoop 1973:88). Lukas het immers op dieselfde wyse te werk gegaan as wat "die beste verteenwoordiger van die Grieks-Romeinse historiografie dit maar kon doen" (Stoop 1973:88). Die eerste leerstoel in kerkgeskiedenis is in 1650 aan die Universiteit van Helmstedt ingestel, om daarna binne enkele jare deur al die vernaamste Protestantse universiteite gevolg te word (Jedin 1973:41; Stoop 1973:86-87). In Rooms-Katolieke geledere het Kerkgeskiedenis as teologiese vakwetenskap eers 'n honderd jaar later in Oostenryk verskyn en is "geestelike geskiedenis" genoem (Jedin 1973:42). Vandag is daar geen teologiese fakulteit van naam wat nie Kerkgeskiedenis as afsonderlike vakwetenskap aanbied nie. Daaruit kan seker die afleiding gemaak word dat die belangrikheid van kerkgeskiedenis in die opleiding van predikante wêreldwyd erken word.

Dit beteken nie dat daar nie steeds beskouinge bestaan dat Kerkgeskiedenis as 'n deel van algemene geskiedenis opgevat moet word en daarom nie onder die teologiese vakke tuishoort nie. Juis hier bring dit vir Kerkgeskiedenis die krisis mee wat reeds ten opsigte van geskiedenis as sodanig bestaan naamlik die historiese kenteoretiese vraagstuk wat so aktueel geword het (vgl Dreyer 1974:232). Van 't Spijker merk hieroor op:

Dit is voor een deel te verklaren uit het relativerend spreken over de geschiedenis binne de stroming van het historisme met zijn opvattingen over kritiek, correlatie en analogie. Het probleem van de 'geschichtlichkeit' als sodanig maakt onze kennis van historische feiten vrij onzeker. Het blijkt dat één en hetzelfde gebeuren verschillend geïnterpreteerd kan worden.

(Van 't Spijker 1980:230) 
Dit het tot gevolg dat daar 'n taamlik wydverspreide opvatting bestaan dat die studie van geskiedenis en dus ook kerkgeskiedenis, dit wil sê die beoefening van geskiedenis-aswetenskap, eintlik ' $n$ redelik sinnelose bedryf is, wat oorgelaat moet word aan daardie verstokte fanatici wat dit geniet om tussen 'n klomp vermufte dokumente in stowwerige argiewe rond te ploeter. Dat dit as sinnelose bedryf beskou word het te make met die opvatting dat geskiedenis en dus ook kerkgeskiedenis nie as wetenskap beoefen kan word nie, omdat dit nie aan die vereistes van wat wetenskap is, voldoen nie (Dreyer 1974:134145). Dreyer het egter oortuigend aangetoon dat geskiedenis inderdaad 'n wetenskap is met 'n spesifieke aard wat hom van ander wetenskappe onderskei. Hy noem 'n aantal vereistes vir 'n wetenskap naamlik die kennis moet rasionele kennis wees, dit moet gefundeer kan word, dit moet objektiewe geldigheid hê, dit moet mededeelbaar wees, dit moet volgens geykte metodes verkry wees, en laastens moet dit ook in 'n bepaalde vorm gegiet kan word wat sistematies, logies en samehangend is (Dreyer 1974:120-136). Ook Kerkgeskiedenis kan aan hierdie vereistes voldoen en kan daarom as akademiese wetenskap beoefen word.

Die afkeer bestaan egter nie net in die geskiedenis as wetenskap nie. Baie wil ook van die sinvolheid van die geskiedenis-as-verlede-werklikheid, niks weet nie (Dreyer 1974:1). Trouens een van die tendense van die sogenaamde hordemens,'n term van Ortega y Gasset, is sy afkeer in die geskiedenis (Dreyer 1974:19). Die verlede moet liefs totaal vergeet en buite rekening gelaat word in die eksistensiële bestaan hier en nou.

Dit is nie onmoontlik dat 'n stelling van Karl Barth, wat "een enigszins dubieuze bekendheid" (Van 't Spijker 1980:230) verwerf het, sommige van hierdie negatiewe opvattings ten opsigte van die beoefening van Kerkgeskiedenis as 'n teologiese dissipline, verder in die hand gewerk het nie. Sy uitspraak was naamlik: "Die sogenannte Kirchengeschichte antwortet auf keine Selbständig zu stellen Frage hinsichtlich der christlichen Rede von Gott und ist darum nicht als selbständige theologische Disziplin aufzufassen" (Kirchliche Dogmatik, I, 1 S.3).

Dit is egter nie al wat Barth oor Kerkgeskiedenis gesê het nie. In $K D$ III, $3 \mathrm{~S}$. 234 stel hy die saak tot 'n groot mate reg en ken hy baie duidelik 'n eie funksie toe aan Kerk- en Dogmengeskiedenis binne die teologie. Dan verklaar hy selfs van Kerkgeskiedenis: 
Man sieht dann wohl die ganze Geringfügigkeit der Kirchengeschichte inmitten des übrigen Geschehens dieser sogenannten ära. Man versteht dann aber auch den Anspruch, den die Kirche zu allen Zeiten für die Bedeutung gerade ihrer Geschichte erhoben hat. Man schämt sich dann seiner nicht, und man verleugnet ihn nicht. Man muß es dann sogar selber theoretisch und vor allem praktisch bekennen: es ist schon so, daß die Kirchengeschichte aller übrigen Geschichte gegenüber die Priorität hat, daß kirchliche inmitten alles übrigen Geschehens in seiner gansen Unscheinbarkeit, Torheit und Verworrenheit das zentrale, das das entscheidende Geschehen ist, zu dem alles übrige doch nur so etwas wie Hintergrund und Begleitmusik ist. ... Man wird aber die erkenntnis, daß unsere uns noch gegebene Zeit tatsächlich die Zeit der Kirche ist, nicht preisgeben können.Und eben in ihrem Vollzug steht man vor der Kirchengeschichte als vor der zusammenhängenden Spur der Weltregierung dessen, in dessen Namen die Kirche ihren so bescheidenen, so problematischen Dienst tut, der doch der höchste ist.

In die grond van die saak gaan dit om die vrae: waarom belangstelling in die geskiedenis van die kerk; waarom navorsing, bestudering en beskrywing van die geskiedenis van die kerk en ten slotte waarom die onderrig van die geskiedenis van die kerk as vak aan studente in die teologie? Anders gestel: dit gaan om die vraag na die waarde, betekenis en sin van die beoefening van Kerkgeskiedenis as 'n teologiese dissipline. Luister 'n mens na die uitspraak van die filosoof Hegel oor geskiedenis naamlik dat al wat 'n mens uit die geskiedenis leer, is dat 'n mens nooit enigiets uit die geskiedenis leer nie (vgl Sterrenberg 1994:36), dan kom dit voor asof die beoefening van enige soort geskiedenis nutteloos en waardeloos is. As daarteenoor George Santayana waarskuwend sê: "Those who cannot remember the past are condemned to repeat it" (aangehaal deur Sterrenberg 1994:36), kan dit seker wel tot belangstelling in en ywerige naspeuring van die verlede lei. Uit eie geledere het ds Jac van Belkum die tragiese gevolge verwoord van nalatigheid oor die verlede: "Immers een volk dat zijne geschiedenis vergeet is als een kind, dat zijn ouderlijke woning vergeten kan" (NHKA Sarkady:L VI 26/18). 
Op hierdie punt is dit van belang om oor teologie die volgende duidelik voor oë te hou:

$[D]$ ie teologie 'n groep wetenskappe is wat uitgaan van die veronderstelling van die geloof in die openbaring van God in die Bybel en daarom die Bybel tot doel en voorwerp van studie het; vanuit die Bybel tree die teologie die wêreld binne, maar word in hierdie intrede deur die Bybel gelei, bepaal en begrens. Wanneer ons van geloof praat, impliseer ons reeds kerk, omdat die geloof gewek en in stand gehou word deur die werking van die Heilige Gees in en met die verkondiging van die Woord en die bediening van die sakramente. Die teologie staan dus nie los van die kerk nie, maar is 'n wetenskapsbeoefenig vanweë die kerk en ter wille van die kerk en is gerig daarop om uit te mond in die verkondiging van die Evangelie deur die kerk.

(Dreyer [1967]:142)

Hierby kan 'n opmerking van Heyns en Jonker oor wat teologie is, gevoeg word naamlik: "die sistematiese antwoord van hom wat weet dat hy deur God in sy Woord aangespreek is, en nie anders kan as om hom daarmee op 'n wetenskaplike wyse besig te hou nie" (Heyns \& Jonker 1974:130).

Teologie is dus wetenskapsbeoefening ten dienste van die kerk wat uitgaan van die vooronderstelling van geloof in die God van die Bybel. Terwyl teologie 'n eenheid is, val dit tog in verskillende dissiplines uiteen "na gelang die bepaalde verband waarin dit tot die Heilige Skrif staan" (Coertzen 1991:151). Verder is dit ook baie belangrik om daarop te wys dat teologie self 'n historiese verskynsel is, wat uit sy aard oor die geskiedenis-as-verlede-werklikheid besin en juis daarom ook met geskiedenis-aswetenskap in 'n verhouding tree (Dreyer [1967]:141,vgl ook Van Ruler 1978:31-32). Van Ruler merk hieroor op: "De stof der theologische wetenschap is over de gehele linie histories bepaald. Zelfs de meest systematische der theologische disciplines, de dogmatiek, dient zich, zal zij niet in filosofie overgaan, het historische karakter van het wezen en van de werken Gods voortdurend voor de geest te houden" (Van Ruler 1978:32). Terloops kan die vraag hier gestel word: As Kerkgeskiedenis afgeskaf sou word, word die basis van teologie nie daarmee weggeslaan nie? By uitstek is dit Kerkgeskiedenis as 'n volledige historiese vakwetenskap binne die teologie, wat hom 
besig hou met die kerkgeskiedenis-as-verlede-werklikheid en juis daarom in 'n bepaalde verhouding met die geskiedenis-as-wetenskap moet opereer. Kerkgeskiedenis is immers ten volle historiese en teologiese wetenskap (Botha 1980:8). Om maar net een saak te noem: die vak kerkgeskiedenis deel met die vak geskiedenis die historiese metode (Pont 1998:201-204).

Die groot verskil tussen die twee kom egter by die begrip kerk wat in die een geval bykom. Onmiddellik moet dan ook gestel word dat die begrip kerk op sy beurt ook nie deur alle kerkhistorici eenduidig verstaan word nie, met die gevolg dat daar ook verskil word oor die inhoud en omvang van studieveld en ook oor die begrip en interpretasie van die kerkgeskiedenis (Botha 1980:4). Opmerkings van Kurt-Victor Selge en Hubert Jedin in die verband moet gelyk gegee word. Eersgenoemde het gestel: "Gegenstand der Kirchengeschichte ist die christliche Kirche. Einfach genug, so mag es scheinen. Aber was ist die christliche Kirche - als Gegenstand der Kirchengeschichte betrachtet" (Selge 1982:1)? Laasgenoemde se uitspraak was: "Vom begriff der Kirche hängen Verständnis und Sinngebung der Kirchengeschichte ab" (Jedin 1963:3). Vir die vak Kerkgeskiedenis in die opleiding van Hervormde predikante is die kerkbegrip verwoord in Artikel 27 van die Nederlandse Geloofsbelydenis en in die Heidelbergse Kategismus. Vraag en Antwoord 54. In hierdie departement is dit hoe die kerk gesien word. Beoefening van die Kerkgeskiedenis is nie 'n saak wat van die konfessie losgemaak kan word nie, ook nie van die eie konfessie nie (Van 't Spijker 1980:231).

Die verskil tussen geskiedenis-as-wetenskap en kerkgeskiedenis-as-wetenskap gaan egter nog verder omdat by kerkgeskiedenis as teologiese wetenskap geloof as voorvereiste geld. Geloof in die God van die Bybel bring 'n besondere verstaan en waardering van die geskiedenis en kerkgeskiedenis mee. Vanuit die geloof is dit moontlik om oor die waarde en ook die sin van geskiedenis en kerkgeskiedenis te kan praat. Juis hier blyk dit baie duidelik dat dit nie net belangrik is nie maar selfs onontbeerlik dat Kerkgeskiedenis in die teologiese kurrikulum ingesluit moet wees om deeglik opgeleide en gevormde, dit wil sê kandidate wat behoorlik toegerus is, vir die kerk te lewer.

Wat leer die Skrif dan oor die waarde van geskiedenis en dus ook kerkgeskiedenis? Pont se bevinding hieroor is die volgende: "Die verlede verswaar die 
verantwoordelikheid van die hede vir die toekoms. Die verband tussen die verlede en die hede beteken dat die geslag van vandag 'n groter verantwoordelikheid teenoor die toekoms het, want die gebeurtenisse van gister het nie sommer betekenisloos geword nie" (Pont 1991: Inleiding).

Hieruit volg noodwendig dat dit 'n dure verpligting is vir diegene wat in die hede leef om die gebeure van die verlede noukeurig te bestudeer om dit te ken, juis sodat daar 'n lewende verhouding en verband met die verlede tot stand kan kom of verder versterk kan word (Botha 1980:5; Van Jaarsveld 1959:22). Gebeur dit nie, getuig dit van onverantwoordelikheid en is dit tot hulle nadeel. Die Bybel leer dus dat die verlede nooit heeltemal verby is nie, dat wat gebeur het nie meer uitwisbaar of veranderbaar is nie, en dat die hede se verantwoordelikheid, as môre se verlede, daardeur swaarder gemaak word. Daarom is dit vir die hede van wesenlike belang om voortdurend die verlede na vore te bring en daarna te luister by sy eie beslissings oor wat vir die toekoms nagelaat word, want dit is dan juis die gebeure van die verlede wat die verantwoordelikheid van die hede vir wat aan die toekoms nagelaat word groter en swaarder maak. Die verlede lê in 'n sekere sin 'n las op die hede om die verlede noukeurig na te vors, te verstaan en te interpreteer, en dit dan te betrek en in die oog te hou by die skryf van die eie geskiedenis wat môre en oormôre se verlede sal wees. Die implikasie van hierdie verantwoordelikheid is dat die mens medewerker in die geskiedenis is. Die mens is dus nie 'n stok en 'n blok wat net maar gewillig en willoos moet aanvaar wat oor hom kom en met hom gebeur nie, hy het ook 'n verantwoordelikheid wat hom 'n medespeler maak (Emmen 1942:94-121). Om dit ietwat anders te stel: elke geslag hoef nie de novo te begin nie. Elke hede kan luisterend na die verlede, die spreke wat hy vir die toekoms wil nalaat skep.

Vanuit die geloof kan ook oor die sin van die geskiedenis gepraat word. Prinsipieel is dit onmoontlik om vanuit die geskiedenis-as-wetenskap 'n aanduiding van die sin van die geskiedenis te gee. Die gelowige teoloog egter kan sowel oor die eschaton, dit is die finale einde van die geskiedenis as oor die telos, dit is die finale doel of hoogste waarde van die geskiedenis iets sê. Dan beweeg hy wel nie op die vlak van die wetenskaplike navorsing en rasionalisering nie, maar dan gaan dit om belydenis en verkondiging (Dreyer 1967:155-162). Vir die geloof is daar een sentrale en alles- 
beheersende middelpunt wat aan die geskiedenis sin gee en dit is die gebeurtenis van die indaling van God in die mensegeskiedenis in sy seun Jesus Christus. Jesus Christus is die verklarende sin van die geskiedenis (Pont 1957:5-7, 1991, vgl ook Berkhof 1958).

As dit geld van geskiedenis in die algemeen, dan geld dit seker soveel te meer van die geskiedenis van die kerk. Dit plaas uiteraard 'n geweldige verantwoordelikheid op die vak Kerkgeskiedenis wat as opdrag het die navorsing, bestudering, beskrywing en onderrig van die geskiedenis van die kerk. Met Ernst Benz (soos vertolk deur Stoop 1975:5-6) kan saamgestem word as hy stel dat Kerkgeskiedenis se funksie in teologie is om die selfkennis, selfbewuswording en selfbegrip van die kerk te dien asook om gewete vir die kerk te wees.

Die doel wat Kerkgeskiedenis as teologiese dissipline dus voor oë moet hou, is om 'n lewende verhouding en verband tussen die afgelope of verbygegane kerkgeskiedenis-as-werklikheid en die kerk en lidmate van die huidige oomblik tot stand te bring, sodat die kerk en die lidmate tot 'n deeglike selfkennis en selfbegrip kan kom sodat hulle die swaarder verantwoordelikheid wat die verlede-gebeure op hulle in die hede plaas kan verstaan en hulle kan help toerus om hulle verantwoordelikheid in die hede met die oog op die toekoms na te kom.

As dit is wat vanuit die geloof gesien die waarde en die sin van die geskiedenis en die kerkgeskiedenis is, is dit ondenkbaar dat ' $n$ kandidaat wat in diens van die kerk wil gaan staan nie minstens redelik onderlê sal wees in die geskiedenis van die kerk in die algemeen en meer bepaald oor die geskiedenis van die besondere kerk in wie se diens hy of sy wil tree nie. Die eie kerk as arbeidsterrein, as die primêre adres waar die Evangelie afgelewer moet word, moet deeglik geken en begryp word ten opsigte van sy besondere identiteit, etos, selfbeeld, teologiese tradisie, kerklike orde, en so meer. Omdat 'n kerk voortsetting is van sy eie geskiedenis, is behoorlike kennis van die eie geskiedenis onontbeerlik vir sy predikante. Kennis en begrip van die eie, kweek immers waardering en liefde vir die eie. Die voorwaarde is wel dat die eie wat identiteit, etos, teologiese tradisie, kerklike orde en so meer betref, voldoen aan die norme van die Skrif. Dit is feitlik vanselfsprekend dat waar die eie kerkgeskiedenis deeglike aandag geniet, dit 'n besondere geleentheid bied om 'n bydrae te lewer tot die vorming van die gesindheid van 
'n student wat hom vir die predikantskap in die Nederduitsch Hervormde Kerk geskik kan maak (vgl Kerkorde Ordinansie 2.1.1.3 (iii) (d), asterisk 2).

In 'n kerk wat op goeie gronde daarop aanspraak maak om histories en regmatig voortsetting van die kerk van Jesus Christus te wees, is dit vanselfsprekend dat die geskiedenis van die algemene kerk ook hoog waardeer sal word en van soveel belang dat van sy predikante verwag sal word om ook daarvan genoegsame kennis te hê. Eers as 'n predikant ' $n$ behoorlike kennis van die geskiedenis van die eie kerk en die nodige kennis van die algemene kerkgeskiedenis het, of anders gesê: eers as daar by die predikant self 'n lewende verband met die kerkgeskiedenis-as-verlede-werklikheid tot stand gekom het, kan die predikant self met insig dienswerk gaan lewer in lyn en in aansluiting met die verlede. Kerkgeskiedenis word immers nie aan 'n teologiese student aangebied as 'n stuk breingimnastiek wat net van akademiese belang is en met die oog op die praktiese dienswerk liefs so gou as moontlik vergeet behoort te word nie. Dit is van lewensbelang omdat hy self ook die verantwoordelikheid het om as bemiddelaar by die lidmate dieselfde lewende verband met die verlede van die kerk te gaan lê of te gaan bevorder. In die Nederduitsch Hervormde Kerk word hierdie verantwoordelikheid inderdaad ook kerkordelik bepaal. Die predikant ontvang uitdruklik die opdrag om kategetiese onderrig te gee (Kerkorde Ordereël 2.1.5 (d)), wat inhou dat hy nie alleen self kategese aanbied nie, maar dat hy ook die kategete toerus (Kerkorde Ordinansie 2.1.5 (vi)). Die kategese word aangebied aan die hand van kategeseboeke wat deur die Algemene Kerkvergadering vasgestel is (Kerkorde Ordinansie 5.1.1 (v); vgl ook Kerkorde Ordinansie 5.3.2) en in die kategesehandboeke word die kerkgeskiedenis wel aan die orde gestel (bv Leer Hulle 8:73-94). Die predikant ontvang saam met die ouderlinge die verantwoordelikheid dat in die finalejaarkategese "die kennis van die Bybelse inhoud en die leer van die Kerk by elke katkisant tot afronding kom, dat elke katkisant 'n oorsig oor die kerkgeskiedenis het, dat hulle deelname aan die sakramente begeer en dat hulle verantwoordelike lidmate sal wees" (Kerkorde Ordinansie 5.3.3; my beklemtoning).

Kerkgeskiedenis kan egter ook besonder belangrike ondersteuning bied aan 'n predikant wat sy primêre opdrag naamlik die verkondiging van die evangelie, betref. Hou in gedagte dat die doel van verkondiging in werklikheid ook is om 'n lewende 
verband tussen die mens van vandag en die boodskap van meer as tweeduisend jaar gelede tot stand te bring. In die Kerkorde word die uitdruklike opdrag gegee dat die prediking kerklik gerig sal word onder andere deur:

(ii) besondere dae, naamlik:

(c) Bartholomeusnag waarin die geloof van die martelare gedenk word, op die Sondag naaste aan 24 Augustus.

(d) Hervormingsondag op die laaste Sondag van Oktober (Ordinansie 5.1 .5 (ii) (c) en (d)).

(iii) die leer van die Kerk soos vervat in die belydenisse en belydenisskrifte en in die besonder deur die Heidelbergse Kategismus in 'n siklus van drie jaar (Ordinansie 5.1.5 (iii)).

Om aan hierdie opdragte daadwerklik en behoorlik uitvoering te gee, kan beswaarlik realiseer sonder genoegsame kennis van die kerk- en dogmageskiedenis van die vroeë kerk sowel as van die Reformasie. Ds Jac van Belkum, self 'n deeglike kenner van die Kerkgeskiedenis, het dit ook nog uitgelig dat die Kerkgeskiedenis selfs op 'n ander wyse vir die prediking ook nog belangrik kan wees, naamlik vanweë die voorbeelde en vergelykingsmateriaal wat daaruit geneem kan word (Van Belkum 1915:6).

\section{KERKREG}

Oor Kerkreg kan kort gehandel word. Ook ten opsigte van die vak Kerkreg is daar al geargumenteer dat dit nie by die teologiese wetenskap nie, maar by die regswetenskap tuishoort. Die radikaalste uitspraak in die verband is deur die Leipziger-geleerde Rudolph Sohm gemaak naamlik dat kerkreg in teenspraak is met die wese van die kerk, omdat die kerk geestelik is en die reg wêreldlik (Coertzen 1919:12-18; Van der Watt 1973:116). Sy uitgangspunt was dat die kerk 'n volstrekte geestelike realiteit is, "die onsigbare liggaam van Christus, wat slegs deur gemeenskaplike geloof en pneumatiese charismata (gawes) byeengehou word en daarom geen uitwendige organisasie nodig het nie" (Van der Watt 1973:116). 'n Groot en in die Nederduitsch Hervormde Teologie gewaardeerde teoloog, Emil Brunner het by hom aangesluit (Coertzen 1991:21). Teenoor 
hulle het Karl Barth onomwonde standpunt ingeneem en betoog "dat juis in die orde van die kerk die gehoorsaamheid van die gemeente aan sy Hoof gemanifesteer word" (Van der Watt 1973:116; vgl Coertzen 1991:21). Ook Otto Friedrich het aangetoon dat Sohm se kerkbegrip en regsbegrip onaanvaarbaar is (Coertzen 1991:21).

In die gereformeerde Protestantse kringe van Europa bestaan daar nie veel twyfel dat Kerkreg wel in die teologiese fakulteit tuishoort nie, hoewel daar nie altyd eenstemmigheid is saam met watter van die teologiese dissiplines die vak gerangskik moet word nie (Coertzen 1991:153-154, Van der Watt 1973:119; König 1973:22, voetnoot 5). Teologiese fakulteite waarin daar nie vir 'n bepaalde kerk predikante opgelei word nie, vertoon wel die neiging om Kerkreg as vak totaal uit te skakel (König 1973:23).

Op plaaslike bodem is in die kerke van die Calvinistiese tradisie nog nooit oor die teologiese aard van die kerkreg getwyfel nie (Coertzen 1991:156, vgl Van Wyk 1989:24). Kerkreg word ook nie in isolasie van die ander dissiplines bedryf nie, maar is gesteld op kontak, nie net met Kerkgeskiedenis nie, maar met al die dissiplines, en veral met die Bybelwetenskappe en Dogmatiek.Dit blyk egter dat die mees ongeforseerde indeling van Kerkreg is om dit saam met Kerkgeskiedenis te groepeer, veral waar 'n opleiding met die eie besondere kerk se kerkreg besig sou wees en daar ook aan die besondere kerk se eie geskiedenis aandag gegee word (Van der Watt 1973:119).

Om die vraag te kan beantwoord wat Kerkreg is, kan 'n keuse gemaak word uit 'n wye verskeidenheid definisies wat al gegee is. Die groot Nederlandse kerkregkundige van die sewentiende eeu, Gijsbertus Voetius (1589-1676), wat sy lesings onder die titel Politica Ecclesiastica aangebied het, het Kerkreg beskryf as "scientia sacra regendi ecclesiam visibilem (die heilige wetenskap vir die regering van die sigbare kerk)" (Coertzen 1991:26 en 159). Hierdie definisie van Voetius berus op en is navolging van Johannes Calvyn se standpunt "dat dit volgens die Heilige Skrif duidelik is dat die kerk van Christus op aarde 'n vaste regeringsvorm moet hê in ooreenstemming met die uitsprake van die Woord van God" (Coertzen 1991:152). In die vorige eeu het nog 'n bekende Nederlandse teoloog, T H L Haitjema (1951:7), in sy werk Nederlands Hervormd Kerkrecht verklaar: "Kerkrecht heeft als vak van wetenschap te doen met de systematische beschrijving van 'de orde in het leven en werken der Kerk'". Daar moet 
egter duidelikheid oor die kerkbegrip wat ter sake is bestaan naamlik: "het kerkbegrip, dat als 'locus de ecclesia' in de dogmatiek uit Schrift en confessie opbloeit en tegelijk naar Schrift en cofessie genormeerd wordt, de lichtende ondergrond van alle kerkrechtelijke regelingen blijven moet" (Haitjema 1951:8). Die kerkbegrip soos genormeer deur Skrif en konfessie is ook in hierdie wetenskap van deurslaggewende betekenis.

Uit eie geledere meen Pont dat Kerkreg as vakwetenskap binne die teologie die vraag tot taak het hoe die feit dat Jesus Christus die enigste Hoof en Heer van sy kerk is, prakties hier op aarde verwerklik moet word (Pont 1981:3, vgl ook Pont 1983:18). Van Wyk stel dit kort en saaklik: "dit is die deel van die teologie wat hom besig hou met die bestudering van die Woord van God met die oog op die regte orde vir die kerk van die Here" (Van Wyk 1989:24). As 'n eie poging word aangebied: Kerkreg is die teologiese wetenskap wat besig is met die voortdurende navorsing en nadenke vanuit bepaalde bronne aan die hand van metodologiese bakens oor, en die beskrywing van 'n gepaste struktuur wat gehoorsaamheid aan God kan manifesteer (Botha 1993:8-11).

Dat dit ' $n$ voortdurende taak is, vloei voort uit die opvatting van die Reformatore dat die Skrif nie 'n volledige en pasklaar struktuur vir alle tye, omstandighede en plekke gee nie en ook uit hulle uitgangspunt ecclesia reformata semper reformanda verbo dei. Die primêre en normerende bron is die Heilige Skrif, die sekondêre en genormeerde bron is die belydenisskrifte, en daarna die bestaande en vroeëre kerkordes, besluite van regeervergaderings en geskrifte van kerkregtelikes en ander kundiges. As hier van struktuur en gehoorsaamheid gepraat word, gaan dit in wese om twee kante van dieselfde saak. Gehoorsaamheid kan gesien word as die innerlike en struktuur as die uiterlike of sigbaargeworde dop van gehoorsaamwees as reaksie en gevolg van die werking van die Heilige Gees deur die Woord. Die struktuur van die kerk is dus nie maar net van tweederangse belang wat aan die toeval of aan die willekeur van gelowiges oorgelaat kan word nie. Dit is net soveel 'n opdrag wat gehoorsaam moet word as wat die gawe van God in Christus geloof vra. Die kerk, met die plaaslike gemeente as die normale verskyningsvorm, wat deur die heilsdaad van God in Christus in 'n herstelde verhouding met Hom geplaas is en wat dit in die geloof ontvang en aanvaar, moet op daardie Godgegewe plek so funksioneer dat dit gepas en ordelik sal wees. Alleen dan kan dit tot eer van die God van vrede en orde wees en tot opbou van die gemeente (Botha 1993:5). 
Uit die enkele opmerkings wat gemaak is, is die duidelike konklusie egter te trek dat Kerkreg 'n teologiese dissipline is wat 'n dienende karakter het, of ook anders gestel: Kerkreg is nie 'n laboratoriumwetenskap nie, maar 'n wetenskap te velde, wat nie maar net in die akademiese wêreld afgesonder wil bly nie, maar wat met sy resultate na die kerklike regeervergaderings wil gaan om oor die praktiese implementering daarvan te besluit (Smit 1987:17). Die Kerkreg sien graag dat sy resultate in die kerk strukture aanneem. Kerkreg kan dus gesien word as 'n duidelik prakties-gerigte teologiese wetenskap wat egter nooit in pragmatisme durf verval nie. Ook hier bied die feit dat die eie kerk se kerkregtelike agtergronde en kerkordelike reëlings besondere aandag geniet, die geleentheid tot vorming soos wat die Nederduitsch Hervormde Kerk verwag.

Baie kort kan daarom gestel word dat 'n predikant wat as dienaar van die Woord ten nouste betrokke is by die orde en dissipline in en van die kerk, wat inhou dat hy of sy die Kerkorde behoorlik moet kan hanteer en daarom ook die nodige kennis moet hê wat die Kerkorde ten grondslag lê, ongetwyfeld met Kerkreg in die opleiding en vorming kennis moes maak.

\section{SLOT}

Konkluderend word gestel: 'n Kerk wat sy verlede vergeet of doelbewus geringskat of totaal negeer, is soos 'n mens wat aan geheueverlies ly: hy weet nie waar hy vandaan kom nie, daarom weet hy nie regtig wie hy is nie en daarom weet hy ook nie waarheen hy op pad is nie. 'n Kerk wat in nederige ootmoed die heil wat God in Jesus Christus aanbied aanvaar, soek voortdurend na die gepaste struktuur om in elke tyd en onder elke omstandigheid gehoorsaamheid aan God te manifesteer. Daarom is Kerkgeskiedenis (en Dogmageskiedenis) en Kerkreg steeds belangrik en selfs onontbeerlik in die teologiese opleiding en vorming van studente.

\section{Literatuurverwysings}

Barth, K 1950. Kirchliche Dogmatik I, 1, S 3. Zurich: Evangelisher Verlag Zollikon. Barth, K 1950. Kirchliche Dogmatik III, 3, S 234. Zurich: Evangelisher Verlag Zollikon. Berkhof, H 1958. Christus de zin der geschiedenis. Nijkerk: Callenbach. 
Botha, S J 1980. Kerkgeskiedenis in die konteks van die Hervormde Teologiese Opleiding aan die Universiteit van die Noorde. (Universiteit van die Noorde, Reeks C nr 56.)

Botha, S J 1981. Ds Marie Joseph Goddefroy 1848-1920. Pretoria: Haum.

Botha, S J 1993. Die heil, gehoorsaamheid, struktuur en Kerkreg. (Universiteit van Pretoria, Nuwe Reeks no 285.)

Coertzen, P 1991. Gepas en ordelik. RGN: Pretoria

Dreyer, P S [1967]. Hoofprobleme van die filosofie en die teologie van die geskiedenis. HTS, 22(4), 141- 162.

Dreyer, P S 1974. Inleiding tot die filosofie van die geskiedenis. Kaapstad: Haum.

Emmen, E 1942. De geschiedenis-waardeering der Reformatie in Geschiedenis. Assen: Van Gorcum.

Haitjema, Th L 1951. Nederlands Hervormd Kerkrecht. Nijkerk: Callenbach.

Heyns, J A \& Jonker, W D 1974. Op weg met die teologie. Pretoria: NG Kerkboekhandel.

Jedin, H 1973. Einleitung in die Kirchengeschichte in Baus, in Jedin, H, Handbuch der Kirchengeschichte, Band I, S 1-10. Freiburg: Herder.

Johanson, B 1973. Praktiese Teologie, in Eybers, I A, König, A \& Stoop, J A A A, Inleiding in die teologie, 169-180. Pretoria: N G Kerkboekhandel.

Kerkorde van die Nederduitsch Hervormde Kerk van Afrika, 1998.

König, A 1973. Die Teologiese wetenskap, in Eybers, I A, König, A \& Stoop, J A A A, Inleiding in die Teologie, 9-27. Pretoria: NG Kerkboekhandel.

Leer Hulle 8, 1989. Handleiding vir kategete. Pretoria: Kital.

Louw, H J 2000. Kritiese bestudering van die verband tussen Secor Dabar as teologiese studentevereniging aan die Universiteit van Utrecht en Van der Hoff as teologiese studentevereniging aan die Universiteit van Pretoria. BD-Skripsie, Universiteit van Pretoria.

Oberholzer, J P 1967. Na vyftig jaar: Deel 1, in Gedenkalbum Teologiese Fakulteit 19171967, 15-23. NHW Pers: Krugersdorp.

Oberholzer, J P 1992. Terugblikke op die Fakulteit Teologie (Afd A), Universiteit van Pretoria, en sy lede - 'n literatuurverkenning. HTS 48(3 \& 4), 575-584.

Pont, A D 1981. Die historiese agtergronde van ons kerklike reg. Pretoria: HAUM. 
Pont, A D 1983. Vyf en twintig jaar Kerkreg binne die ruimte van die Nederduitsch Hervormde Kerk van Afrika. HTS 39(1), 18-31.

Pont, A D 1992. Kerkgeskiedenis in ons teologiese opleiding 1917-1956. HTS 48(1 \& 2), 253-272.

Pont, A D 1998. Kerkgeskiedskrywing: Hoe skryf ons kerkgeskiedenis? HTS 54(1 \& 2), 197-209.

Sarkady, N sj. Nederduitsch Hervormde Kerk van Afrika. Ongepubliseerde inventaris ds Jac van Belkum versameling: L VI/ 1-32. Argief van die Nederduitsch Hervormde Kerk, Pretoria.

Selge, Kurt-Victor 1982. Einführung in das studium der Kirchengeschichte. Darmstadt: Wissenschaftliche Buchgesellschaft.

Smit, C J 1987. Kerkreg en kerkorde in diens van kerkregering. Oorsig oor 'n beskouing. Die Skriflig 21/82.

Sterrenberg, R J 1994. In search of the human mind. New York: Harcourt Brace Publisher.

Stoop, J A A A 1973. Kerkgeskiedenis, in Eybers, I A, König, A \& Stoop, J A A A, Inleiding in die teologie, 84-110. Pretoria: N G Kerkboekhandel.

Stoop, J A A A \& Viljoen, A C 1975. Kerkgeskiedenis: Module CHH 205, Gids 1. Universiteit van Suid-Afrika.

Van Belkum, J 1915. De Hervormer.

Van 't Spijker, W 1980. Het theologisch karakter van de Kerkgeschiedenis. Theologia Reformata, 1980, 230-245.

Van der Watt, P B 1973. Kerkreg, in Eybers, I A, König, A \& Stoop, J A A A, Inleiding in die Teologie, 111-121. Pretoria: NG Boekhandel.

Van Jaarsveld, F A 1959. Die Afrikaner en sy geskiedenis. Kaapstad: HAUM.

Van Ruler, A A 1978. Verwachting en voltoö̈ng. Callenbach:Nijkerk.

Van Wyk, B J 1989. Die presbiteriaal-sinodale kerkbegrip met besondere verwysing na die Kerkwet van die Nederduitsch Hervormde Kerk van Afrika. DD-proefskrif, Universiteit van Pretoria.

Wetten en Bepalingen voor de Nederduitse Hervormde Kerk van Afrika 1925. Het weste-drukkery: Potchefstroom. 